\title{
Comparison of e-Learning, Blended and Traditional English Teaching Methods: A Case Study of Ban Hong Community Education College
}

\author{
Sayoomporn Promsurin and Jirapa Vitayapirak
}

\begin{abstract}
With the global interest in computers, innovative teaching methods have been oriented to English language learning environments. The objectives of this research were to compare the effectiveness of the three English teaching methods, i.e. e-learning, blended learning, and traditional instruction and assess students' satisfaction. The samples were 90 first year vocational certificate students who enrolled on an English course in the academic year 2013 at Ban Hong Community Education College, Thailand. Those students were divided into three groups of 30, i.e. two experimental groups and one control group by using simple random sampling. The first experimental group was taught through e-learning instruction, the second experimental group was taught through blended learning instruction, whereas the control group was taught through traditional instruction. The study was conducted two hours a week for eight weeks period. The main findings indicated that blended learning instruction can significantly increase the students' achievement scores and the students show highly positive satisfaction towards learning language English.
\end{abstract}

Index Terms-E-Learning, blended learning, traditional instruction, English teaching method, students' satisfaction, Thai.

\section{INTRODUCTION}

One of the biggest symbols of our modern age is the computer. Education has definitely been effected by the digital world. The fast moving technology provides people in the area of education with limitless opportunities. Innovative teaching methods have been oriented to foreign language learning environments. English is one of the most important languages in the world and the only language that truly links the world together in the global economy [1].

In Thailand, the Thai Ministry of Education is committed to develop education using technology. During 2007-2011, the Ministry of Education's ICT Master Plan supported Thailand's learning society aspirations by enabling all Thai citizens to experience the benefits of ICT. Interactive Elearning Project was initiated and aimed to provide distance learning through an educational satellite link. The intention was to bridge the gap between rural and city schools and also to give students in rural areas a chance to interact with experienced teachers. During 2012-2015, Thai government

Manuscript received September 19, 2014; revised May 20, 2015.

Sayoomporn Promsurin is with the Deparment of Applied Linguistics (English for Science and Technology), King Mongkut's Institute of Technology Ladkrabang, Thailand (e-mail: ym_yoom@hotmail.com).

Jirapa Vitayapirak is with the Faculty of Industrial Education, King Mongkut's Institute of Technology Ladkrabang, Thailand (e-mail: kvjirapa@kmitl.ac.th). promoted the use of Information and Communication Technology (ICT) to equalize education at international level. In order to enhance the educational opportunities, the government therefore had many projects such as 'one tablet per child' with free Wi-Fi in public areas, learning rooms with educational software and e-books. E-learning programs and contents were developed to change schools to life-long learning centers and to promote knowledge-based society [2].

For Vocational Education, it aims to prepare the students for the work force, i.e. to provide knowledge for career preparation and work experiences in many areas together with technological application [3]. One of the Vocational Education Standards indicated that students should be able to communicate using Thai, English and other languages in daily life and career [4]. In the work place, most of the employers want to have competent graduates who are able to communicate in English with IT competency. Therefore, the vocational colleges need to prepare vocational students with a good program that serves the needs of the work force in terms of language skills, IT competency, problem-solving, and lifelong learning [2].

Due to the fact that the use of English has increased dramatically and as a result there is a lack of English teachers in Thailand. Thai students like other as EFL students have to stride into the world of technology which has been proven to be a motivating tool for communicative language teaching and provide authentic tasks and audiences for English language learners locally and globally [5]. According to [6], they studied the use of technology in English language teaching and learning. They found that technology plays a very important role in English teaching. Using multimedia to create a context to teach English has its unique advantages. Additionally, [7] argued that using various kinds of media in the classroom can help with many issues in language teaching such as: motivation, enhancement of student's understanding and improvement of their accuracy and fluency.

We can see from the previous research that e-learning can play important role in English teaching. This research is the attempt to examine the effectiveness of using e-learning, blended learning and traditional (face-to-face) English language teaching methods for vocational students at Ban Hong Community Education College, Lamphun, Thailand.

\section{RESEARCH OBJECTIVES}

The objectives of this research were to compare the students' achievement of English language learning using elearning, blended learning, and traditional (face-to-face) 
instruction and assess students' satisfaction toward elearning, blended learning, and traditional (face-to-face) instruction.

\section{RESEARCH QUESTIONS}

1) Are there any differences in students' achievement in English language learning using e-learning, blended learning, and traditional (face-to-face) instruction?

2) What are the effects of e-learning, blended learning, and traditional (face-to-face) instruction on students' satisfaction?

\section{VARIABLES}

The independent variables are English teaching methods based on e-learning, blended learning, and traditional (face- to-face) instruction.

The dependent variables are the achievement test scores and satisfaction of students using e-learning, blended learning, and traditional (face-to-face) instruction.

\section{Population AND SAMPLE}

The population in this study was vocational certificate students at Ban Hong Community Education College in the second semester of the academic year 2013. The samples of the study were 90 first year vocational certificate students who enrolled on the "Real Life English 2" course. These students were divided into two experimental groups, i.e. elearning, blended learning and one control group, i.e. traditional instruction, 30 students each, by simple random sampling.

TABLE I: GENERAL DATA OF THE STUDENTS

\begin{tabular}{|c|c|c|c|c|c|c|c|c|c|}
\hline \multirow{2}{*}{\multicolumn{2}{|c|}{ Data }} & \multicolumn{2}{|c|}{ E1 Group } & \multicolumn{2}{|c|}{ E2 Group } & \multicolumn{2}{|c|}{ C Group } & \multicolumn{2}{|c|}{ Total } \\
\hline & & $\mathbf{N}$ & $\% \mathrm{t}$ & $\mathbf{N}$ & $\%$ & $\mathbf{N}$ & $\%$ & $\mathbf{N}$ & $\%$ \\
\hline \multirow{2}{*}{$\begin{array}{l}\text { Gender } \\
(N=90)\end{array}$} & Male & 21 & 70 & 26 & 86.67 & 21 & 70 & 68 & 75.56 \\
\hline & Female & 9 & 30 & 4 & 13.33 & 9 & 30 & 22 & 24.44 \\
\hline \multicolumn{2}{|c|}{ Total } & 30 & 100 & 30 & 100 & 30 & 100 & 90 & 100 \\
\hline \multirow{5}{*}{$\begin{array}{c}\text { Fields of } \\
\text { study } \\
(N=90)\end{array}$} & $\begin{array}{c}\text { Auto } \\
\text { Mechanics }\end{array}$ & 11 & 36.67 & 10 & 33.33 & 17 & 56.67 & 38 & 42.2 \\
\hline & $\begin{array}{c}\text { Electronics } \\
\text { Power }\end{array}$ & 7 & 23.33 & 11 & 36.67 & 2 & 6.67 & 20 & 22.2 \\
\hline & Electronics & 3 & 10 & 4 & 13.33 & 1 & 3.33 & 8 & 8.9 \\
\hline & Accounting & 8 & 26.67 & 3 & 10 & 4 & 13.33 & 15 & 16.7 \\
\hline & $\begin{array}{l}\text { Business } \\
\text { Computer }\end{array}$ & 1 & 3.33 & 2 & 6.67 & 6 & 20 & 9 & 10 \\
\hline \multicolumn{2}{|c|}{ Total } & 30 & 100 & 30 & 100 & 30 & 100 & 90 & 100 \\
\hline
\end{tabular}

E1 represents: the first experimental group (e-learning instruction);

E2 represents: the second experimental group (blended learning instruction);

$\mathrm{C}$ represents: the control group (traditional \{face-to-face $\}$ instruction).

Table I indicated that most of all 90 students, there were $75.56 \%$ male and $24.44 \%$ female. Those students were divided into three groups of 30 , i.e. two experimental groups and one control group (21 male, 9 female for the first experimental group: 26 male, 4 female for the second experimental group and 21 male, 9 female for the controlled group). Most of them studied in Auto Mechanics (42.2\%), followed by Electronics Power (22.2\%), Accounting (16.7\%), Business Computer (10\%) and Electronics (8.9\%), respectively.

\section{MATERIALS AND METHODS}

\section{A. Research Instruments}

Research instruments of this study were pre-test and posttest, teaching materials, lesson plans and satisfaction questionnaire.

1) Pre-test and post-test: the tests were selected from the standard language learning test for its validity and reliability. Students were divided into three levels according to the test scores, i.e. high, moderate, and low level. The post-test was used as achievement test to measure students' achievement at the end of the study. The tests are created using six types of multiple-choice question: Picture/Sound Association, Fill-in-the-Blanks, Sound/Meaning Association, Listening Association, Words order, and Listening/Sentence Association. There are some examples of the tests as shown in Fig. 1 below.

2) Teaching materials: a standard language learning software, TELL ME MORE was used for e-learning and blended learning methods because it offers content based on the "Real Life English 2" course description, i.e. professional-type situations as well as situations taken from everyday life. There are some examples of the tests as shown in Fig. 2 and Fig. 3.

3) Lesson plans: the three different types of lesson plan were written, i.e. e-learning, blended learning and traditional (face-to-face) instruction.

4) Questionnaire: a questionnaire was used to study the students' satisfaction through each English teaching method at the end of the study. The questionnaire consisted of 12 items using the 5-point Likert scales of response. 
1. Picture/Sound Association (2 renditions; allotted time: 30 seconds)

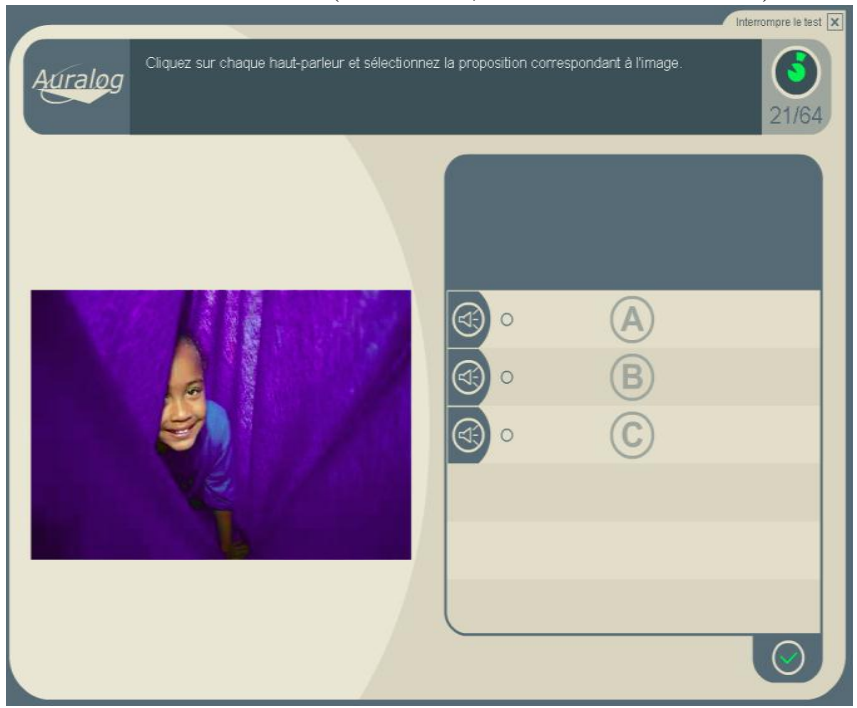

3. Sound/Meaning Association (2 renditions; allotted time: 30 seconds)

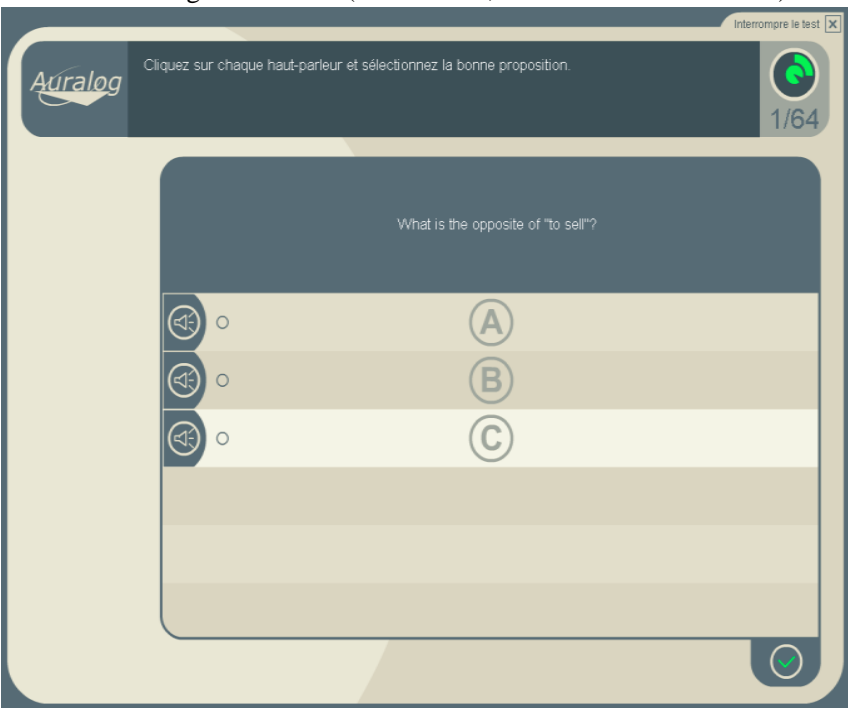

5. Word Order (allotted time: 30 seconds)

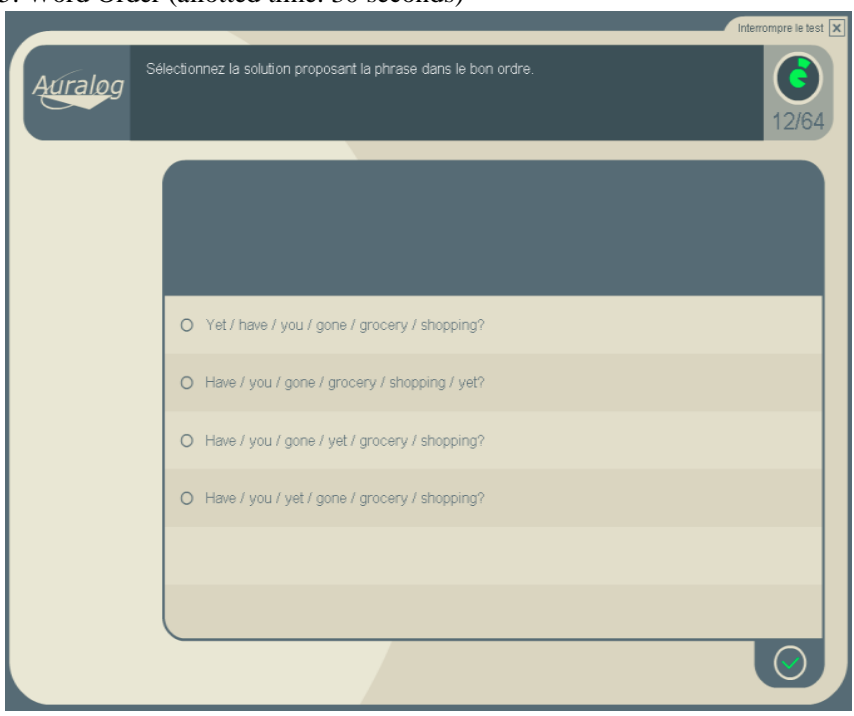

Fig. 1. Pre-test and post-test sample.

The lesson plans and the questionnaire were revised and approved by the experts in the field of English teaching.

\section{B. Research Methodology}

This research was an experimental research comparing
2. Fill-in-the-Blanks (allotted time: 30 seconds)

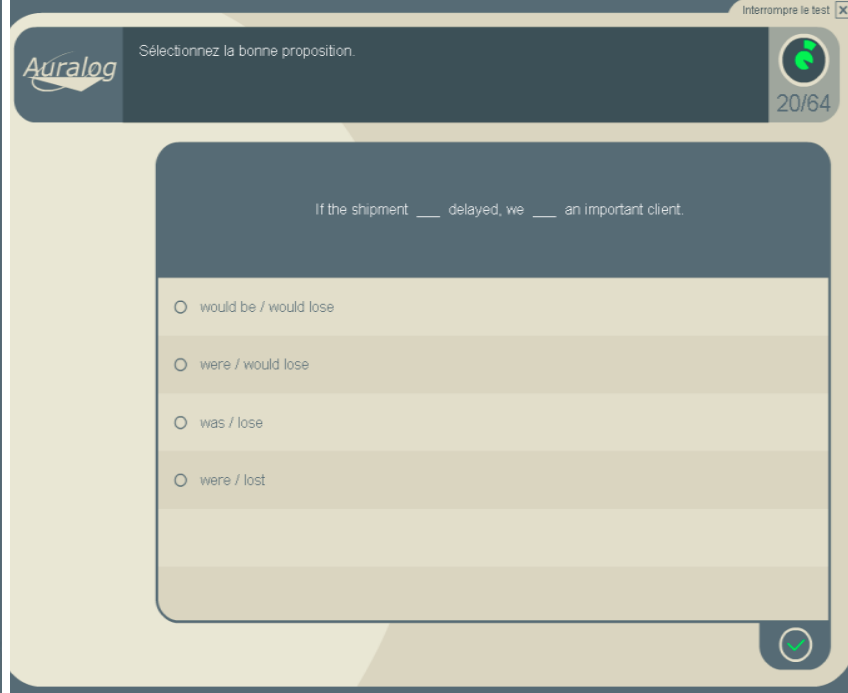

4. Listening Association (2 renditions; allotted time: 30 seconds)

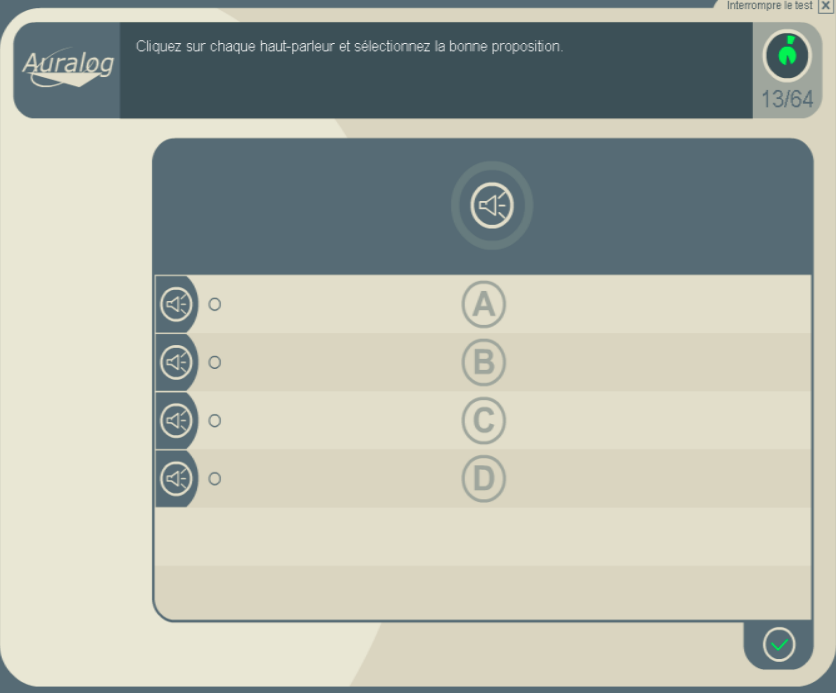

6. Listening/Sentence Association (text) (2 renditions; allotted time: $1 \mathrm{~min}$.)

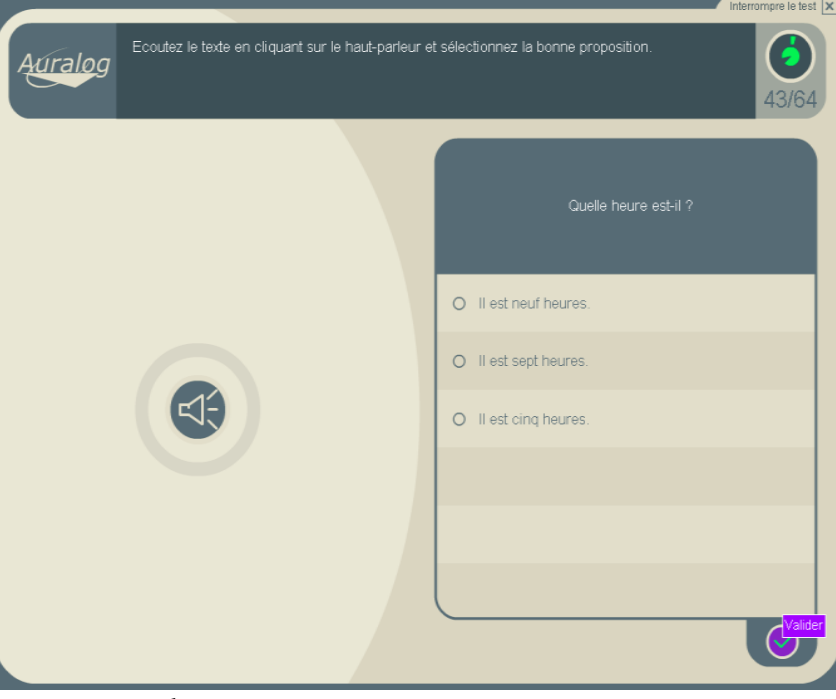

the effectiveness of three English teaching methods: elearning, blended learning and traditional (face-to-face). The participants were divided into two experimental groups and one control group. Hence, it was assumed that those three groups started out with similar level according to the test 
scores, i.e. high, moderate, and low. The first experimental group was taught through e-learning instruction, the second experimental group was taught through blended learning instruction, while the control group was taught through traditional (face-to-face) instruction. The three groups were learnt with the same content and taught by the same teacher. The study was conducted two hours a week for eight weeks period. All groups used teaching processes as shown in Table II below.

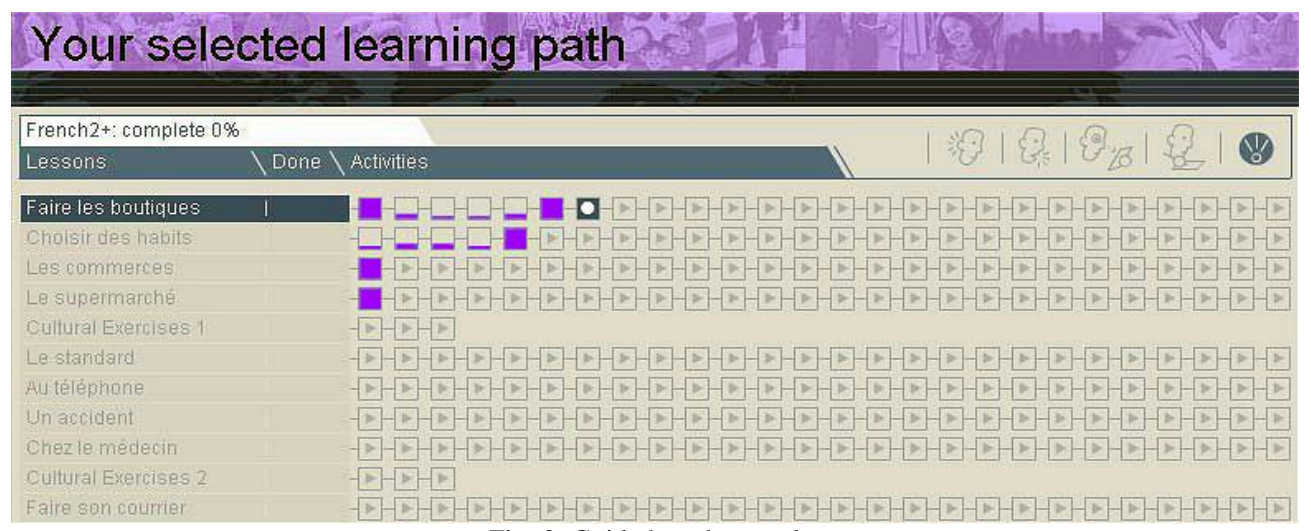

Fig. 2. Guided mode sample.

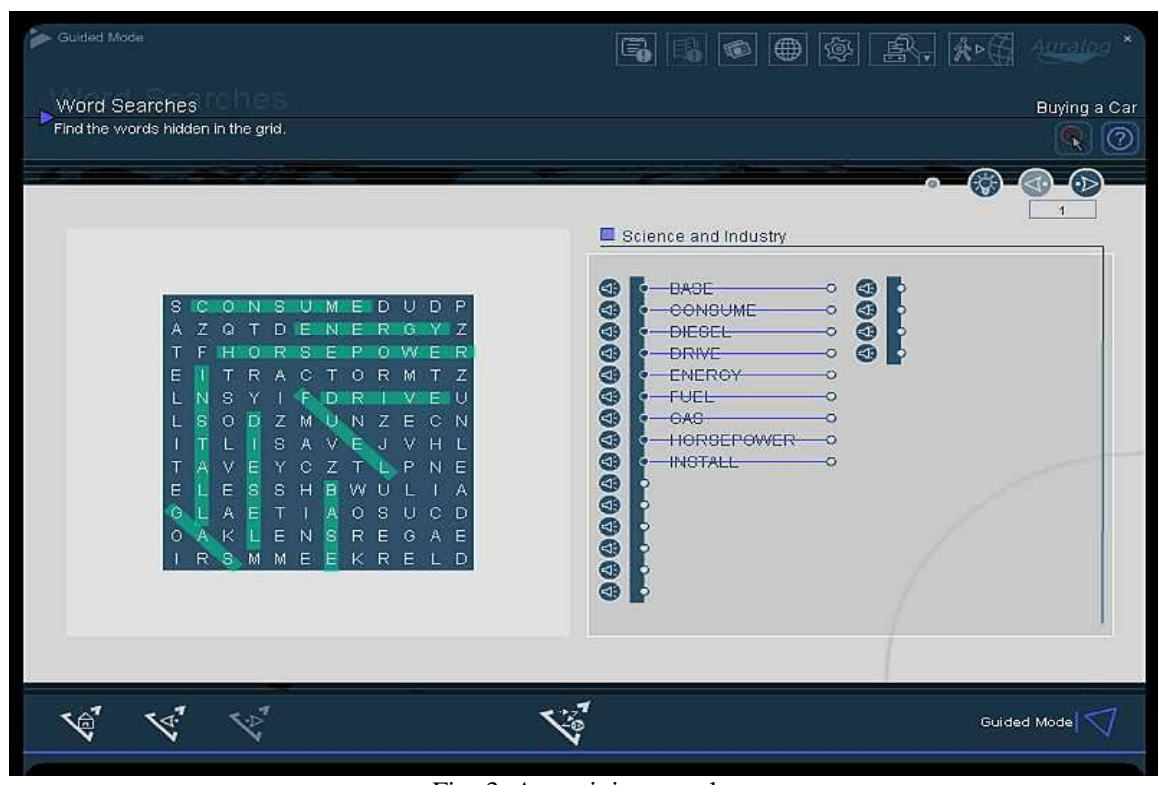

Fig. 3. An activity sample.

TABLE II: TEACHING PROCESSES

\begin{tabular}{llll}
\hline \multicolumn{1}{c}{ Method } & \multicolumn{1}{c}{ E-learning } & Blended learning & $\begin{array}{c}\text { Traditional } \\
\text { (Face-to-Face) }\end{array}$ \\
\hline Instructor & \multicolumn{2}{c}{ The researcher was the instructor. } \\
\hline Materials & $\begin{array}{l}\text { Language } \\
\text { learning software }\end{array}$ & $\begin{array}{l}\text { Textbook and } \\
\text { Language } \\
\text { learning software }\end{array}$ & Textbook \\
\hline Setting & Computer Center & $\begin{array}{l}\text { Classroom and } \\
\text { Computer Center }\end{array}$ & Classroom \\
\hline
\end{tabular}

\section{Data Collection and Analysis}

The data obtained from the pre-test, the post-test and the satisfaction questionnaire were analyzed using mean, standard deviation, percentage, T-test, One-Way ANOVA (F-test) and Scheffe's test.

\section{RESULTS}

\section{A. Student Achievement}

To compare pre-test and post-test scores of all students, the analysis of Dependent Sample T-test was used to find the value of mean and standard deviation, and to compare the differences in the scores of the tests before and after learning

In this study, the results were significant at 0.01 as shown in Tables III and IV below:

TABLE III: MEAN $(\bar{x})$ AND STANDARD DEVIATION (SD) OF PRE-TEST AND

\begin{tabular}{cccc}
\multicolumn{4}{c}{ POST-TEST OF ALL STUDENTS $(N=90)$} \\
\hline & $N$ & Mean & Standard Deviation \\
\hline Pre-Test & 90 & 2.2789 & 0.85584 \\
Post-Test & 90 & 2.6611 & 0.77033 \\
\hline
\end{tabular}

TABLE IV: T-TEST RESUlTS OF PRE-TEST AND POST-TEST SCORES ( $N=90)$

\begin{tabular}{lccccccc}
\hline & $N$ & Mean & $\begin{array}{c}\text { Standard } \\
\text { Deviation }\end{array}$ & $t$ & df & Sig. (2-tailed) \\
\hline $\begin{array}{l}\text { Pre-Test } \\
\text { Post-Test }\end{array}$ & 90 & -0.38222 & 0.57447 & -6.312 & 89 & 0.000 \\
\hline
\end{tabular}

Significance at level 0.01

According to Table III, the mean scores of the post-test were much higher than the mean scores of the pre-test $(\bar{x}=$ 2.6611 and 2.2789 respectively).

Based on the data obtained by pre-test and post-test scores in Table IV, the results of an analysis indicated that 
the t-test result was -6.312 . The p-value was 0.000 which was less than the significant level at 0.01 . Thus, there were significant differences between the two tests.

In order to find out the difference of Students' Achievement, One-Way Analysis of Variance (One-way ANOVA) or F-test was used in finding the relation between the experimental groups and the control group. The result was shown in Table V:

TABLE V: ONE-WAy ANOVA RESUlTS OF ACHIEVEMENT TEST SCORES

\begin{tabular}{lrrrrr}
\hline \multicolumn{6}{c}{$(N=90)$} \\
& $\begin{array}{c}\text { Sum of } \\
\text { Squares }\end{array}$ & df & $\begin{array}{c}\text { Mean } \\
\text { Square }\end{array}$ & F & P \\
\hline Between Groups & 5.870 & 2 & 2.935 & 5.439 & 0.006 \\
\hline Within Groups & 46.944 & 87 & 0.540 & & \\
\hline Total & 52.814 & 89 & & & \\
Significance at level 0.05 & & & & &
\end{tabular}

As in Table $\mathrm{V}$, in testing the relation between the experimental groups and the control groups, it was revealed that the f-value was 5.439. The p-value was 0.006 which was less than 0.05 . This indicated that there were statistically significant differences in two experimental groups and the control group.

Scheffe's test was used to test dependent variables, the result of p-value in each group was shown in Table VI:

\begin{tabular}{cccc}
\multicolumn{4}{c}{ TABLE VI: THE ReSUlt OF P-VAluE IN EACH GROUP } \\
\hline Methods & Methods & Mean Difference & Sig. \\
\hline \multirow{2}{*}{ E-learning } & Blended & $-0.57333^{*}$ & 0.013 \\
\cline { 2 - 4 } & Traditional & -0.07000 & 0.934 \\
\hline \multirow{2}{*}{ Blended } & E-learning & $0.57333^{*}$ & 0.013 \\
\cline { 2 - 4 } & Traditional & $0.50333^{*}$ & 0.034 \\
\hline \multirow{2}{*}{ Traditional } & E-learning & 0.07000 & 0.934 \\
\cline { 2 - 4 } & Blended & $-0.50333^{*}$ & 0.034 \\
\hline \multirow{2}{*}{ Significance at level 0.05} & &
\end{tabular}

Significance at level 0.05

From Table VI, the p-value of blended method was 0.013 and 0.034 which was less than 0.05 . It confirmed that the students' achievement scores in blended learning group were the highest.

To compare achievement test scores of two experimental groups and the control group, the total scores for each group were calculated. Table VI presents grand mean score of three groups.

Table VII shows that the mean score of achievement test of students who received blended learning was the highest ( $\bar{x}=3.0200$ ), followed by traditional (face-to-face) instruction $(\bar{x}=2.5167)$, and the e-learning instruction $(\bar{x}=2.4467)$ respectively.

Following the achievement test scores, the students were placed on a scale of 5 levels from 10 scores, the result in each group was shown in Table VIII.

TABLE VII: MEAN $(\bar{x})$ AND STANDARD DEVIATION (SD) OF ACHIEVEMENT TEST FOR THE TWO EXPERIMENTAL GROUPS AND THE

\begin{tabular}{cccc}
\multicolumn{4}{c}{ Control Group } \\
\hline Group & $N$ & Mean & $\begin{array}{c}\text { Standard } \\
\text { Deviation }\end{array}$ \\
\hline E1 (E-learning) & 30 & 2.4467 & 0.69169 \\
\hline E2 (Blended learning) & 30 & 3.0200 & 0.92192 \\
\hline C (Traditional) & 30 & 2.5167 & 0.53889 \\
\hline Total & 90 & 2.6611 & 0.77033 \\
\hline
\end{tabular}

TABLE VIII: THE LEVEL SCORES OF ACHIEVEMENT TEST

\begin{tabular}{cccccccccc}
\hline \multicolumn{1}{c}{ Level } & Scores & \multicolumn{1}{c}{ E1 Group } & \multicolumn{1}{c}{ E2 Group } & \multicolumn{2}{c}{ C Group } & \multicolumn{2}{c}{ Total } \\
\cline { 2 - 10 } & $\boldsymbol{N}$ & $\mathbf{\%}$ & $\boldsymbol{N}$ & $\mathbf{\%}$ & $\boldsymbol{N}$ & $\mathbf{\%}$ & $\mathbf{N}$ & $\%$ \\
\hline 1 & $\begin{array}{c}1.0- \\
2.0\end{array}$ & 10 & 33.33 & 3 & 10 & 8 & 26.67 & 21 & 23.33 \\
\hline 2 & $\begin{array}{c}2.1- \\
4.0\end{array}$ & 20 & 67.67 & 22 & 73.33 & 22 & 73.33 & 64 & 71.11 \\
\hline 3 & $\begin{array}{c}4.1- \\
6.0\end{array}$ & 0 & 0 & 5 & 16.67 & 0 & 0 & 5 & 5.56 \\
\hline 4 & $\begin{array}{c}6.1- \\
8.0\end{array}$ & 0 & 0 & 0 & 0 & 0 & 0 & 0 & 0 \\
\hline 5 & $\begin{array}{c}8.1- \\
10.0\end{array}$ & 0 & 0 & 0 & 0 & 0 & 0 & 0 & 0 \\
\hline & Total & $\mathbf{3 0}$ & $\mathbf{1 0 0}$ & $\mathbf{3 0}$ & $\mathbf{1 0 0}$ & $\mathbf{3 0}$ & $\mathbf{1 0 0}$ & $\mathbf{9 0}$ & $\mathbf{1 0 0}$ \\
\hline
\end{tabular}

Most of the students (71.11\%) were in level 2 (64 students), followed by level 1 (21 students, or 23.33\%) and level 3 (5 students, or $5.56 \%$ ), while no one could get to level 4 and 5 .

\section{B. Student Satisfaction}

At the end of the study, the post-test was used as achievement test to all groups. Then, the satisfaction questionnaires were given which consisted of twelve items using the 5-point Likert scales of response $(5=$ Very Satisfied, 4 = Satisfied, 3 = Neutral, 2 = Dissatisfied, $1=$ Very Dissatisfied). The questions wereas follows:

1) I am interested in English lesson.

2) I understand English lesson and can use it in daily life.

3) I feel comfortable to learn English.

4) I am enthusiastic in English language learning.

5) I enjoy doing English activities.

6) I have an opportunity for interaction with other students.

7) I have an opportunity for interaction with English teacher.

8) Teacher explains on the problematic points.

9) I prefer to learn with textbook and computer inside the classroom.

10) The instruction improves my English.

11) The instruction is interesting.

12) I am satisfied with the instruction.

When asked the students about their satisfaction on elearning, blended learning, and traditional (face-to-face) instruction using the questionnaire above, the results revealed that the mean level of students' satisfaction range from 3.83-4.53 for the blended learning group, from 3.304.47 for the traditional (face-to-face) instruction group and from 2.17-3.80 for the e-learning group respectively. The result was shown in Table IX below.

Comparisons of differences in students' satisfaction in each group were as follows:

The first group is e-learning, most of students are satisfied in item 9, followed by item 6 , and item 5 respectively. The details are as follows:

1) Item 9 "I prefer to learn with textbook and computer inside the classroom", the result of mean score is 3.80 .

2) Item 6 "I have an opportunity for interaction with other students", the result of mean score is 3.73.

3) Item 5 "I enjoy doing English activities", the result of mean score is 3.70 .

The second group is blended learning, students are very satisfied in item 5, and satisfied in same scores of items $4,9,10$ followed by items 11,12 respectively. The details are as follows: 
TABLE IX: Mean $(\bar{x})$ And STANDARd Deviations (SD) of THE STUdents' Satisfaction On the Three Methods

\begin{tabular}{rccccccccc}
\hline \multirow{2}{*}{ Items } & \multicolumn{3}{c}{ E-learning Group } & \multicolumn{3}{c}{ Blended Group } & \multicolumn{3}{c}{ Traditional Group } \\
\cline { 2 - 10 } & $\overline{\boldsymbol{x}}$ & $\mathbf{S D}$ & $\begin{array}{c}\text { Satisfaction } \\
\text { Level }\end{array}$ & $\overline{\boldsymbol{x}}$ & SD & $\begin{array}{c}\text { Satisfaction } \\
\text { Level }\end{array}$ & $\overline{\boldsymbol{x}}$ & SD & $\begin{array}{c}\text { Satisfaction } \\
\text { Level }\end{array}$ \\
\hline 1 & 3.36 & 0.49 & Neutral & 4.00 & 0.69 & Satisfied & 3.70 & 0.60 & Satisfied \\
\hline 2 & 3.37 & 0.49 & Neutral & 3.83 & 0.53 & Satisfied & 3.47 & 0.51 & Neutral \\
\hline 3 & 3.60 & 0.50 & Satisfied & 4.03 & 0.56 & Satisfied & 3.47 & 0.51 & Neutral \\
\hline 4 & 3.57 & 0.50 & Satisfied & 4.43 & 0.50 & Satisfied & 3.37 & 0.61 & Neutral \\
\hline 5 & 3.70 & 0.47 & Satisfied & 4.53 & 0.51 & Very Satisfied & 3.30 & 0.47 & Neutral \\
\hline 6 & 3.73 & 0.52 & Satisfied & 4.17 & 0.53 & Satisfied & 3.60 & 0.50 & Satisfied \\
\hline 7 & 2.17 & 0.38 & Dissatisfied & 4.37 & 0.56 & Satisfied & 4.13 & 0.51 & Satisfied \\
\hline 8 & 2.20 & 0.41 & Dissatisfied & 4.37 & 0.56 & Satisfied & 4.00 & 0.37 & Satisfied \\
\hline 9 & 3.80 & 0.92 & Satisfied & 4.43 & 0.50 & Satisfied & 4.47 & 0.57 & Satisfied \\
\hline 10 & 3.47 & 0.51 & Neutral & 4.43 & 0.50 & Satisfied & 3.34 & 0.50 & Neutral \\
\hline 11 & 3.47 & 0.51 & Neutral & 4.40 & 0.56 & Satisfied & 3.33 & 0.48 & Neutral \\
\hline 12 & 3.47 & 0.51 & Neutral & 4.40 & 0.56 & Satisfied & 3.33 & 0.48 & Neutral \\
\hline Mean & $\mathbf{3 . 3 5}$ & $\mathbf{0 . 5 2}$ & Neutral & $\mathbf{4 . 2 9}$ & $\mathbf{0 . 5 4}$ & Satisfied & $\mathbf{3 . 3 6}$ & $\mathbf{0 . 5 1}$ & Neutral \\
\hline
\end{tabular}

1) Item 5 "I enjoy doing English activities", the result of mean score is 4.53 .

2) Item 4 "I am enthusiastic in English language learning", item 9 "I like to learn with textbook and computer inside the classroom" and item 10 "The instruction improves the English language learning", these three items have the same level of mean score which is 4.43 .

3) Item 11 "The instruction is interesting" and item 12 "I am satisfied with the instruction", these two items have same mean score which is 4.40 .

The third group is traditional (face-to-face) instruction, most of students are satisfied in item 9 , followed by item 7 , and item 8 . The details are as follows:

1) Item 9 "I prefer to learn with textbook and computer inside the classroom", the result of mean score is 4.47.

2) Item 7 "I have an opportunity for interaction with teacher", the result of mean score is 4.13 .

3) Item 8 "Teacher explains on the problematic points", the result of mean score is 4.00 .

In summary, from the total mean scores, on average the students rated their points of the blended learning group was 4.29 , the traditional (face-to-face) instruction group was 3.36 whereas the e-learning group was 3.35 , respectively.

\section{CONCLUSION AND DISCUSSION}

This study has confirmed the research that advocates blended learning as useful and effective, but contradicted with the argument that supports the use of pure e-learning method only in the classroom for English language learning. Results of an analysis indicated that the post-test scores were much higher than the pre-test scores. This shows that the English learning improved after the course. Students who were instructed through blended learning method scored the highest in the achievement test, followed by the traditional (face-to-face) instruction whereas the e-learning method scored the lowest. Moreover, in this study it was apparent that the satisfaction of students towards blended learning group was at the highest level, followed by the traditional and the e-learning instructions, respectively.

In this study, the results also supported those findings on students' satisfaction since either pure e-learning or traditional face-to-face instruction holds some weaknesses and strengths. It is better to mix the strengths of both learning environments [8]. [9] also indicated that a blended course provides a comprehensive and comparable learning environment to the traditional program. They discovered the positive response to blended learning in terms of overall satisfaction and enjoyment of the lessons.

In conclusion, these research findings lead to conclude that the blended learning is useful and effective in EFL classroom since the students' achievement scores were the highest. Moreover, the blended learning in class can increase the students' positive satisfaction towards learning English.

\section{ACKNOWLEDGEMENTS}

This work was supported in part by Thai Government Fellowship (SP2), Office of Vocational Education Commission. I would like to express my gratitude to Assoc. Prof. Dr. Jirapa Vitayapirak, my advisor, for her valuable suggestions and devotion of time in revising this paper. I would also like to thank Miss Piyanuch Charoensrifor her advice on software use, other suggestions and encouragement.

\section{REFERENCES}

[1] D. N. Sagita, "The effects of teaching writing narration using series pictures in the second grade of Muhammadiyah 10 junior high school at Surakarta," B.Ed. thesis, School of Teacher Training and Education, Muhammadiyah University of Surakarta, Surakarta, Indonesia, 2009.

[2] Ministry of Education. (August 2012). Policies and strategies on Education Development 2012-2015. [Online]. Available: http://www.mis.moe.go.th/misen/images/publication/documents/do cuments/StrategiesEducation\%202012.pdf

[3] Office of the National Education Commission, Education in Thailand 2002/2003, Bangkok: Amarin Printing and Publishing, 2003, p. 21.

[4] Ministry of Education, Thailand. (August 2012). Curriculum for Certificate of Vocational Education (2003 Revised Ed.). [Online]. Available: http://bsq.vec.go.th/course/Eng/certificate_eng.pdf

[5] M. E. Butler-Pascoe and K. M. Wiburg, Technology and Teaching English Language Learners, USA: Pearson, 2003, p. 47.

[6] S. D. Shyamlee and M. Phil, "Use of technology in English language teaching and learning: An analysis," International 
Proceedings of Economics Development and Research, pp. 150-156, 2012.

[7] V. Tafani, "Teaching English through mass media," Acta Didactica Napocesia., vol. 2, no. 1, pp. 81-94, 2009.

[8] F. Z. Azizan, "Blended learning in higher institutions in Malaysia," in Proc. Regional Conference on Knowledge Integration in ICT, 2010, pp. $454-456$

[9] Z. Kocoglu, Y. Ozek, and Y. Kesli, "Blended learning: Investigating its potential in an English language teacher Training Program," Australasian Journal of Educational Technology, vol. 27, no. 7, pp. 1124-1134, 2011.

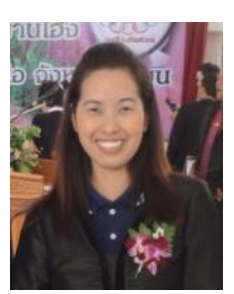

Sayoomporn Pronsurin was born on April 15, 1978, in Bangkok, Thailand. In 2000, she obtained the bachelor of arts (business English) degree at Rajabhat Institute Chiang Mai, Thailand. Then in 2008 she got the graduate diploma in teaching profession at Chiang RaiRajabhat University, Thailand. In 2006-2009, she worked as an English teacher at Chiang Mai College of Agriculture and Technology, Chiang Mai, Thailand.

At present, she is a Thai government English teacher at Ban Hong
Community Education College, Lamphun, Thailand. Her research interest is English language teaching.

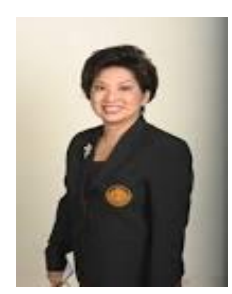

Jirapa Vitayapirak works at the Department of Applied Arts (English), Faculty of Industrial Education, King Mongkut's Institute of Technology Ladkrabang, Thailand. In 1986, she got her M.A. degree in applied linguistics from King Mongkut's University of Technology Thonburi, Thailand. In 2001, she finished her Ph.D. degree in linguistics from Macquarie University, Australia.

Administratively, she was the associate dean for academic affairs at the Faculty of Industrial Education, King Mongkut's Institute of Technology Ladkrabang in 1996. Her research interests are corpus linguistics, lexicography, ESP, ELT and terminology. In 2008, she was the president of the Asian Association for Lexicography (ASIALEX). 